Journal of Social Sciences 5(4): 292-300, 2009

ISSN 1549-3652

(C) 2009 Science Publications

\title{
Short-Run Employment Functions in Manufacturing Industries
}

\author{
${ }^{1}$ Md. Azizul Baten, ${ }^{2}$ Monsur Ahmed Chowdhury, \\ ${ }^{1}$ Anton Abdulbasah Kamil and ${ }^{3}$ Rumana Momtaz \\ ${ }^{1}$ School of Distance Education, University Sains Malaysia, \\ 11800 USM, Penang, Malaysia \\ ${ }^{2}$ Department of Statistics, Shah Jalal University of Science and Technology, \\ Sylhet-3114, Bangladesh \\ ${ }^{3}$ Plant Pathology Division, Bangladesh Agricultural Research Institute, \\ Gazipur, Bangladesh
}

\begin{abstract}
Problem statement: Increasing growth of population and shortage of producing capacity in Bangladesh have caused serious unemployment crisis and has forced the authorities to look for ways to reduce unemployment rate. Due to difference of structure and technology used in economic sectors and activities, the effects of factors on employment are different. So, for the purpose of findings alternatives to reduce unemployment rate in Bangladesh, it is necessary to estimate employment functions in all sectors and activities, analyze the most important factors and variables on these functions. Approach: In this study an attempt had been made to estimate short-run employment functions in manufacturing industries of Bangladesh, which are one of the most important sectors that has formed meaningful percent of country employment and gross national production. Adjustment of employment to its desired level and short run returns to employment had been explored in this study. Results: The model type I in comparison to the model type II of the relationship between value added and employment, which had been found to fit quiet well in Bangladesh manufacturing industries. The results showed that $1 \%$ increase in gross value added leads to $0.379 \%$ increase in employment. The coefficient of lagged employment is positive, indicated that the level of previous years employment increases the present year employment. Conclusion: The result also showed that the employment is negatively related to the real wage rate and the elasticity of employment with respect to real wage is about -0.251. The growth rate of value added exceeded the growth rate of employment in manufacturing industries in Bangladesh.
\end{abstract}

Key words: Value-added, employment, employment functions, growth

\section{INTRODUCTION}

In macroeconomics, one of the controversies question is to whether or not unemployment can be largely attributed to the real wage being too high. The question has been interpreted as essentially an empirical issue. The neoclassical approach suggests that, in the long run, capital-labor substitution and wage flexibility guarantee full employment and, hence, one can derive estimates of the elasticity of employment with respect to the real wage using the neoclassical production function. In addition, the short-run influence of expenditure upon production, employment, hours worked, labor productivity and unemployment have received comparatively little attention. The implications of Oi's hypothesis is examined by ${ }^{[26]}$ with the use of a short-term employment function. The restriction of the employment demand to follow either Cobb-Douglas or the generalized Leontief form gives insignificant wage elasticity but significant employment demand elasticity studied by ${ }^{[17]}$. The short-run movements of employment productivity over the business cycle have received special attention and, consequently, several empirical studies of the relationship between value added and employment have recently been available in $^{[8,11,18,19,24,29]}$. As argued by ${ }^{[24]}$ that the methodology of estimating employment functions do not founder on the shoals of algebraic tautology, which diminish the estimates of some estimates of aggregate production functions, as noted by ${ }^{[27]}$.

There have been a number of studies on the employment function have been investigated in

Corresponding Author: Md. Azizul Baten, School of Distance Education, University Sains Malaysia, 11800 USM, Penang, Malaysia Tel: +604 6534746 Fax: +604 6576000 
manufacturing industries. Some of these have been undertaken for developed countries e.g., ${ }^{[8,30,32]}$. The way $^{[2,3,12-14,17,26,28]}$ provide no support or only weak support for a negative value of the elasticity of employment demand with respect to wage rate in industries. Some others undertaken in the context of developing countries e.g., ${ }^{[1,9,21,25]}$ but in general, not found empirical support for a negative value of the elasticity of employment demand with respect to wage rate in manufacturing industries. By contrast, a study undertaken by ${ }^{[3,15,16]}$ on NBER manufacturing industry database, supplemented by data from the OECD database has come up with empirical evidence that clearly a negative value of the elasticity of employment demand with respect to wage rate. In addition, the logarithm of the real wage rate is statistically significantly inversely related to logarithm of employment shown by ${ }^{[2]}$, even when it is known by construction that employment is not a function of the real wage.

The studies discussed above are different but all are estimating the effects of different variables on employment through productivity. Since employment demand depends on a number of factors besides value added, it becomes important to identify the factors, besides value added, which may explain the relatively faster rate of employment absorption. To study the effect of the value added and lagged-employment on the industrial employment, the estimation of an employment function is necessary for the manufacturing industries of Bangladesh. This study explores the short-term employment function to know relationships between employment and value added in the manufacturing industries of Bangladesh and estimates the other important things in the study which are related to refer to scale and adjustment of employment to its desired level.

In this study, first we report on the results of an empirical investigation of the relationship between value added and employment in the manufacturing industries of Bangladesh. Our purpose in undertaking this investigation has been three-fold. First, we wish to ascertain whether the model which has been found to fit quite well in Bangladesh manufacturing industries. Second, we wish to present some tentative explanations of the manufacturing industries of Bangladesh in the parameter estimates of the model. Such explanations may ultimately enable us to develop a more general model in which these parameters are themselves dependent variables. The evidence, which will be presented in this study, has led us to the conclusion that the basic model has considerable explanatory power for the movements of employment in the manufacturing industries of Bangladesh and that the estimated parameters will suggest for further modifications of the model. In this study, third we show that it is possible to obtain a negative value of the elasticity of employment demand with respect to wage rate, even though there may be no behavioral relationship involved.

\section{MATERIALS AND METHODS}

Basic explanation of short-term employment functions: For cyclical productivity fluctuations might be summarized thus: Employers are aware of an optimal or 'desired' level of employment corresponding to each rate of value added and probably subject to nonincreasing returns. However, with gross value added varying, they do not generally wish to adjust employment fully to its varying optimal levels in each time period because of costs of change-adjustment costs. These adjustment costs are such that at low rates of value added more than the desired amounts of labor is held by employers and at high rates employers have less labor than they would ideally wish, the overall effect being to smooth out fluctuations in observed employment relative to fluctuations in output and desired employment. Adjustment costs are due to the costs involved in hiring, firing and training labor, reinforced by uncertainty about the future and it is assumed that they generate an adjustment function of the general form:

$$
E_{t}-E_{t-1}=f\left(E_{t}^{*}-E_{t-1}\right)
$$

Where:

$\mathrm{f}=$ Some function

$\mathrm{E}_{\mathrm{t}}^{*}$ and $\mathrm{E}_{\mathrm{t}}=$ The desired and actual levels of employment in period $\mathrm{t}$

f therefore gives the actual change in employment as a function of the desired change, with $\mathrm{E}_{\mathrm{t}-1}$ the number of workers on hand at the beginning of period $t$. The optimal level of employment for a period is generally supposed to be determined by the planned rate of output, the state of technology and the stock of capital on hand. For simplicity, the planned rate of output is usually proxied by actual output and capital and technology are bundled together into a trend term, so that:

$$
\begin{aligned}
& \mathrm{E}_{\mathrm{t}}^{*}= \mathrm{g}\left(\mathrm{V}_{\mathrm{t}}, \mathrm{t}\right) \\
& \text { Combining (1) and (2): } \\
& \mathrm{E}_{\mathrm{t}}-\mathrm{E}_{\mathrm{t}-1}=\mathrm{f}\left(\mathrm{g}\left(\mathrm{V}_{\mathrm{t}}, \mathrm{t}\right)-\mathrm{E}_{\mathrm{t}-1}\right)
\end{aligned}
$$


The specification of short-run employment function also incorporates a Koyck adjustment mechanism of actual employment input towards its desired level i.e.:

$$
\frac{E_{t}}{E_{t-1}}=\left(\frac{E_{t}^{*}}{E_{t-1}}\right)^{\lambda}, \quad 0 \leq \lambda \leq 1
$$

Where:

$\mathrm{E}_{\mathrm{t}}=$ Actual employment input at time $\mathrm{t}$

$\mathrm{E}_{\mathrm{t}}^{*}=$ The desired level of employment input

$\lambda=$ The speed of adjustment of employment towards the desired level

Data description and variables: The main source of data is the annual report of the Census of Manufacturing Industries (CMI), which was collected from Bangladesh Bureau of Statistics (BBS). Our area study covers all 3-digited census factories, under registered manufacturing sector of Bangladesh over the period 1981-82-1999-2000. The estimates at constant prices $(1981-82=100)$ are derived.

Value added (V): Gross value added figures are used in this study to represent value added and is equal to gross output minus industrial cost. Industrial costs include cost of raw materials, fuel and electricity. We use value added instead of net value added to avoid the arbitrariness involved in depreciation estimates. To obtain the gross value-added series in 'constant prices', the yearly current values were deflated by industry price indices to obtain real measure of value added.

Employee (E): The number of employees directly or indirectly engaged in production is used in this study as employment. It covers all workers, including administration, technical, clerical sales and purchase staff so that all production and non-production workers except temporary daily casuals and unpaid workers are included in the analysis. In brief, they include production workers, salaried employees and working proprietors. The best measure of employment is the number of hours worked. The number of employees was weighted by the base year wage rates to obtain measures of employment.

Wage rate $(\mathbf{W})$ : Money wage rate was employment cost divided by number of employees. Employment cost includes wages salaries, cash and non-cash benefits paid to all employees excluding payment made to contract employee. Wage rate represents average remunerations including money value of benefits and privileges per person employed. Wage rate is deflated by consumer price indices to construct real measure of wage rate index.

Model: The two seminal attempts to construct a model of cyclical employment functions for ${ }^{[4,5]}$. We base our exposition on the approach of ${ }^{[4]}$, since there has become the standard type of models.

The main features of this model are as follows:

The observed level of employment in manufacturing is assumed to be demand determined. Supply constraints are either entirely absent or quantitatively unimportant. Since our analysis covers only manufacturing, the assumption that supply constraints are unimportant may not be too restrictive ${ }^{[5]}$.

The typical entrepreneur regards his sales, his capital stock and his techniques of production as exogenous in the short run. All three may change, however, owing to long-run decisions taken by the entrepreneur or owing to factors entirely outside his control.

There is a constant relationship between sales and output, so that output can be treated as exogenous ${ }^{[10]}$. Consequently, the entrepreneur's desired employment services $\left(E_{s}\right)$ can be written as a function of the three exogenous variables, namely gross value-added $\left(\mathrm{V}_{\mathrm{t}}\right)$, capital $\left(K_{t}\right)$ and techniques of production $(T)$ :

$$
E_{s}=f\left(V_{t}, K_{t}, T\right)
$$

In accordance with conventional theory, we expect $E_{s}$ to rise with a rise in $V_{t}$ and to fall with a rise in $K_{t}$ or a rise in $\mathrm{T}$.

Employment services $\left(\mathrm{E}_{\mathrm{s}}\right)$ have two dimensions, namely the number of men employed (E) and the average hours worked. Thus, given the level of $\left(E_{s}\right)$, the entrepreneur must make a joint decision on the optimal number of men and the optimal number of hours. If he is assumed to minimize total employment costs, then the optimal number of men employed $\left(E^{*}\right)$ will be influenced by the exogenously given level of normal or standard hours $(\mathrm{H})$, above which overtime rates of pay apply and by the ratio of overtime to standard pay, $\left(\frac{\mathrm{w}_{2}}{\mathrm{w}_{1}}\right)$. In symbols, the relationship between the desired level of employment $\left(\mathrm{E}^{*}\right)$ and its determinants can be written as ${ }^{[23]}$ :

$$
E^{*}=F\left(E_{s}, H, \frac{w_{2}}{w_{1}}\right)
$$

where, $\mathrm{E}^{*}$ will rise with a rise in $\mathrm{E}_{\mathrm{s}}$ but it may rise or fall with increases in $\mathrm{H}$ or $\frac{\mathrm{w}_{2}}{\mathrm{w}_{1}}$. 
For the present purposes it is assumed that the functional forms of Eq. 4 and 5 are log-linear. Further, owing to the lack of appropriate data, we must assume that the capital stock $\left(\mathrm{K}_{\mathrm{t}}\right)$ and Technology $(\mathrm{T})$ can be approximated by a time trend and that normal hours $(\mathrm{H})$ and the ratio of overtime to standard pay $\left(\frac{\mathrm{w}_{2}}{\mathrm{w}_{1}}\right)$. are either constant or vary smoothly over time. Consequently, Eq. 4 and 5 reduce to:

$\log \mathrm{E}_{\mathrm{t}}^{*}=\beta_{0}+\beta_{1} \log \mathrm{V}_{\mathrm{t}}+\beta_{2} \mathrm{t}$

where, $\mathrm{t}$ stand for time.

Entrepreneurs are assumed to adjust to their desired level of employment with a lag. There are two reasons for this lag. First, changes in the level of employment have costs which are likely to rise with the speed of adjustment. Second, entrepreneurs may not be certain about future levels of $\mathrm{E}^{*}$ and, hence, they may not adjust fully to current changes in $\mathrm{E}^{*}$. A convenient lag structure is the well-known stock adjustment process according to which:

$$
\log E_{t}-\log E_{t-1}=\left(1-\alpha_{3}\right)\left(\log E_{t}^{*}-\log E_{t-1}\right)
$$

or

$$
\log \mathrm{E}_{\mathrm{t}-1}=\left(1-\alpha_{3}\right) \log \mathrm{E}_{\mathrm{t}}^{*}+\alpha_{3} \log \mathrm{E}_{\mathrm{t}-1}
$$

where, $\left(1-\alpha_{3}\right)$ is the proportion of the logarithmic difference between actual and desired employment which is eliminated in the current period. The lag of actual employment behind desired employment implies that if actual employment exceeds (falls short of) desired employment actual hours must all short of (exceed) desired hours ${ }^{[23]}$.

When Eq. 6 and 7a are combined, obtained the following equation by ${ }^{[6]}$ which is identical with the one used by ${ }^{[4]}$ :

$\log \mathrm{E}_{\mathrm{t}}=\alpha_{0}+\alpha_{1} \log \mathrm{V}_{\mathrm{t}}+\alpha_{2} \mathrm{t}+\alpha_{3} \log \mathrm{E}_{\mathrm{t}-1}$

According to Eq. 6-8, the $\beta^{\prime}$ s can be obtained from the $\alpha^{\prime}$ s by the following formula: $\beta_{\mathrm{i}}=\frac{\alpha_{\mathrm{i}}}{1-\alpha_{3}}$. We obtain least squares estimates of the $\alpha^{\prime}$ s.

Assumptions: These models are derived from production function under the following assumptions:

- The production technology is represented by a Constant Elasticity of Substitution (CES) production function and employment in industry adjusts partially to its desired level

- The log structure underlying the model requires the coefficient of lag-employment to be a positive fraction.

- The level of employment, prevailing technology and capital is constant and value-added determines the growth rate

- Capital and technology can be approximated by a time trend

- Entrepreneurs adjust to their desired level of employment with lag

- Employment supply conditions and other factors are quantitatively unimportant

Model type I: We modify the basic Eq. 8 following ${ }^{[2]}$ to be used in this present study:

$\log \mathrm{E}_{\mathrm{t}}=\alpha_{0}+\alpha_{1} \log \mathrm{V}_{\mathrm{t}}+\alpha_{2} \mathrm{t}+\alpha_{3} \log \mathrm{E}_{\mathrm{t}-1}+\alpha_{4} \log \mathrm{w}_{\mathrm{t}}$

Where:

$\mathrm{E}_{\mathrm{t}}=$ The employment in year $\mathrm{t}$

$\mathrm{V}_{\mathrm{t}}=$ The gross value added in year $\mathrm{t}$

$\mathrm{t}=$ The time trend variable

$\mathrm{E}_{\mathrm{t}-1}=$ The employment in year $\mathrm{t}-1$

$\mathrm{w}_{\mathrm{t}}=$ The wage rate in year $\mathrm{t}$

$\alpha_{1}=$ The short-run employment elasticity with respect to value added

$\alpha_{2}=$ The coefficient of time trend which is a proxy variable for capital and technology

The adjustment coefficient of employment to its desired level is $\delta=1-\alpha_{3}$. The long run employment elasticity with respect to value added denoted by $\gamma_{1}=\frac{\alpha_{1}}{1-\alpha_{3}}$. The long-run employment elasticity with respect to time trend denoted by $\gamma_{2}=\frac{\alpha_{2}}{1-\alpha_{3}}$. The short run elasticity of employment with respect to wage rate is given $\alpha_{4}$ and the long-run employment elasticity with respect to wage rate denoted by $\beta=\frac{\alpha_{4}}{1-\alpha_{3}}$. The short run returns to employment or short-run returns to scale is given by $\zeta=\frac{1-\alpha_{3}}{\alpha_{1}}$. Annual rate of technical progress is $\mathrm{P}=-\frac{\alpha_{2}}{\alpha_{1}}$.

The variable time trend $\mathrm{t}$ is used for representing the effects of technology and capital on employment. The variable lag-employment $\mathrm{E}_{\mathrm{t}-1}$ is used for estimating 
the coefficient of adjustment of employment with its desired level. The desired level of employment is the optimal number of men employed to minimize the total employment cost. The adjustment coefficient of employment to its desired level indicates the percentage of any difference between the logarithms of desired and actual employment during the year.

Model type II: We modify the specification of the loglinear employment function (8) following ${ }^{[6]}$ to be used in this study:

$\log \mathrm{E}_{\mathrm{t}}=\tilde{\alpha}_{0}+\tilde{\alpha}_{1} \log \mathrm{V}_{\mathrm{t}}+\tilde{\alpha}_{2} \log \mathrm{E}_{\mathrm{t}-1}$

Where:

$\mathrm{E}_{\mathrm{t}}=$ The employment in year $\mathrm{t}$

$\mathrm{V}_{\mathrm{t}}=$ The gross value added in year $\mathrm{t}$

$\mathrm{E}_{\mathrm{t}-1}=$ The employment in year $\mathrm{t}-1$

The short run elasticity of employment with respect to value added is given by $\tilde{\alpha}_{1}$. The adjustment coefficient of employment to its desired level is $\tilde{\delta}=1-\tilde{\alpha}_{2}$, and the long-run employment elasticity with respect to value added denoted by $\tilde{\gamma}=\frac{\tilde{\alpha}_{1}}{1-\tilde{\alpha}_{2}}$. The short run returns to employment is given by $\tilde{\zeta}=\frac{1-\tilde{\alpha}_{2}}{\tilde{\alpha}_{1}}$.

Test for serial correlation: Durbin-Watson test procedure assumes that the data matrix should be nonstochastic. It is violated or cannot be used when there is lagged-dependent variable as independent variable among regressors. Durbin has derived an alternative large sample h-statistic for testing serial correlation. Then, we used the following test statistic:

$$
h=(1-d / 2) \sqrt{\left(\frac{n}{1-n \operatorname{var}\left(\hat{\eta}_{1}\right)}\right)}
$$

Where:

$$
\begin{array}{ll}
\mathrm{d} & =\text { Durbin Watson (DW) statistic } \\
\mathrm{n} & =\text { Sample size } \\
\operatorname{var}\left(\hat{\eta}_{1}\right) & =\text { Estimate of variance of } \hat{\eta}_{1} \\
\hat{\eta}_{1} & =\text { Coefficient of lagged variable }
\end{array}
$$

\section{RESULTS}

Estimations for the model type I: The estimated Eq. 9 is presented below (standard errors in parenthesis) (Table 1): $\log \mathrm{E}_{\mathrm{t}}=1.450+0.285 \log \mathrm{V}_{\mathrm{t}}+0.174 \mathrm{E}-03 \mathrm{t}+0.522 \log \mathrm{E}_{\mathrm{t}-1}-0.251 \log \mathrm{w}_{\mathrm{t}}$

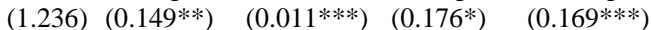

Adjusted $\mathrm{R}^{2}=0.958, \mathrm{DW}=1.583$, Sample No. $=19$

* Denote statistical significance at 5\% level respectively

** Denote statistical significance at $10 \%$ level respectively

*** Denote statistical insignificant

The following values of $\delta, \beta, \gamma_{1}, \gamma_{2}, \zeta$ and $\mathrm{P}$ are derived from the estimated parameters of the employment function (9):

$$
\begin{aligned}
& \delta=\left(1-\alpha_{3}\right)=1-0.522=0.478, \quad \beta=\alpha_{4} / 1-\alpha_{3}=-0.525, \\
& \gamma_{1}=\alpha_{1} / 1-\alpha_{3}=0.596, \gamma_{2}=\alpha_{2} / 1-\alpha_{3}=-0.0191, \\
& \zeta=1-\alpha_{3} / \alpha_{1}=1.677, P=-\alpha_{2} / \alpha_{1}=-0.03219
\end{aligned}
$$

Estimations for the model type II: The estimated Eq. 10 is presented below (standard errors in parenthesis):

$$
\begin{aligned}
& \log E_{t}= 0.412+0.379 \log V_{t}+0.600 \log E_{t-1} \\
&(0.328) \quad\left(0.115^{*}\right) \quad\left(0.128^{*}\right)
\end{aligned}
$$

Adjusted $\mathrm{R}^{2}=0.955, \mathrm{DW}=1.616$, Sample No $=19$

* Denotes statistical significance at 5\% level

The following values of $\tilde{\delta}, \tilde{\gamma}$ and $\tilde{\zeta}$ are derived from the estimated parameters of the employment function (10):

$$
\begin{aligned}
& \tilde{\delta}=\left(1-\tilde{\alpha}_{2}\right)=1-0.600=0.400, \quad \tilde{\gamma}=\tilde{\alpha}_{1} / 1-\tilde{\alpha}_{2}=0.948, \\
& \tilde{\zeta}=1-\tilde{\alpha}_{2} / \tilde{\alpha}_{1}=1.055
\end{aligned}
$$

In comparing both employment functions, the model type I found to fit better and appear to perform satisfactory in Bangladesh manufacturing industries.

Table 1: Matrix of zero order correlation coefficients

\begin{tabular}{llllll}
\hline & $\mathrm{E}_{\mathrm{t}}$ & $\mathrm{V}_{\mathrm{t}}$ & $\mathrm{E}_{\mathrm{t}-1}$ & $\mathrm{t}$ & $\mathrm{W}_{\mathrm{t}}$ \\
\hline $\mathrm{E}_{\mathrm{t}}$ & 1 & 0952 & 0.966 & 0.966 & 0.012 \\
$\mathrm{~V}_{\mathrm{t}}$ & - & 1.000 & 0.918 & 0.955 & 0.060 \\
$\mathrm{E}_{\mathrm{t}-1}$ & - & - & 1.000 & 0.959 & 0.101 \\
$\mathrm{t}$ & - & - & - & 1.000 & 0.077 \\
$\mathrm{~W}_{\mathrm{t}}$ & - & - & - & - & 1.000 \\
\hline
\end{tabular}


Table 2: Annual growth rates in value added and employment Growth rate (percent per annum)

\begin{tabular}{|c|c|c|}
\hline \multirow[b]{2}{*}{ Period } & \multicolumn{2}{|c|}{ whn rate (percent per annum) } \\
\hline & Value added & Employment \\
\hline 1981-1982-1990-1991 & 0.8376 & 0.8198 \\
\hline 1991-1992-1999-2000 & 1.1193 & 0.6626 \\
\hline $1981-1982-1999-2000$ & 0.9217 & 0.7660 \\
\hline
\end{tabular}

\section{DISCUSSION}

For the Model Type I, we found the adjusted $\mathrm{R}^{2}=0.958$ which indicates that about $96 \%$ variations in employment is explained by variations in value added, lagged-employment, the time trend and wage rate. The coefficient of time trend is negative and insignificant and violates the hypothesis that capital and technology can be approximated by a time trend. The long-run employment elasticity with respect to time trend coefficient $\gamma_{2}=-0.0191$ shows that the negative time trend. The employment elasticity with respect to value added is positive but inelastic (0.285) indicates that although increase in value added leads to increase in employment but this is not proportionate. It is observed from our results that $1 \%$ increase in value added leads to $0.285 \%$ increase in employment. The result also shows the positive relationship between lagged employment and present employment. The coefficient of lagged employment $\mathrm{E}_{\mathrm{t}-1}$ is positive and it indicates that elasticity of employment with respect to lagged employment is positive and inelastic (0.522). The level of previous year employment increases the present year employment but it is not proportionate. This result is also consistent with the implication of Eq. 7 namely that (1$\alpha_{3}$ ) should lie between zero and unity.

The estimated adjustment coefficient $\delta=0.478$ indicates that adjustment of employment to desire employment takes place in Bangladesh. The adjustment coefficient $(\delta)$ indicates that there are approximately $50 \%$ variations between desired and actual level of employment during the time period. The elasticity of employment with respect to wage rate is negative (0.251 ) which supports the findings of ${ }^{[18]}$. This variation in wage rate leads to a variation in employment in the manufacturing sector. The short-run elasticity of employment with respect to wage rate is 0.251 and the long run elasticity is 0.525 . Thus it appears that $1 \%$ increase in the wage rate will, others things remaining the same, reduce employment by $0.25 \%$ within one year and its cumulative effect will be to reduce employment by $0.525 \%$. The short-run elasticity of employment with respect to value-added is 0.285 and the long-run elasticity is $\gamma_{1}=0.596$. The finding of a less than unitary elasticity of employment with respect to value- added indicates that increase in value-added will lead to a less than proportionate increase in employment. The value of $\gamma_{1}$ raise some special and important problem and we have found attention to the fact that the value of $\gamma_{1}$ is below unity. This means that a rise in value added (V) of $1 \%$ is normally associated with a rise in optimal level of employment $\mathrm{E}^{*}$ of less than $1 \%$ or alternatively, that a rise in $\mathrm{E}^{*}$ of $1 \%$ is normally associated with a rise in $\mathrm{V}$ of more than $1 \%$. This is actually refers to this phenomenon as "short-run increasing returns to employment". This also supports with the results of ${ }^{[33]}$. The value of $\zeta$ as short-run returns to employment (1.677) seems unreasonably high. It suggests that increasing returns to employment in manufacturing industries of Bangladesh. The value of $\mathrm{P}(-0.031219)$ can be interpreted that the annual rate of technical progress in Bangladesh reduces 3.12\%, which is undesirable.

The computed value of "h" statistic is 1.417 from equation number (11) and "h" statistic is distributed normally with mean zero and variance unity. For $95 \%$ level of confidence the critical value is \pm 1.645 . Since the computed value of h-statistic (1.417) is in acceptance region, we can accept the null hypothesis that residuals are serially independent.

For model type II, we found the adjusted $\mathrm{R}^{2}=$ 0.955 which indicates that about $96 \%$ variation in employment is explained by variations in value added, lagged-employment.

The short-run employment elasticity with respect to value added is positive but inelastic (0.379) indicates that although increase in value added leads to increase in employment but this is not proportionate. It appears from our results that $1 \%$ increase in value added leads to $0.379 \%$ increase in employment. The long-run employment elasticity with respect to value added is $\tilde{\gamma}=0.948$. A less than unitary elasticity of employment with respect to value-added indicates that increase in value-added will lead to a less than proportionate increase in employment. The result also shows the positive relationship between lagged employment and present employment. The coefficient of lagged employment $\mathrm{E}_{\mathrm{t}-1}$ is positive and indicates that elasticity of employment with respect to lagged employment is positive and inelastic (0.600). The level of previous year employment increases the present year employment but it is not proportionate.

The adjustment coefficient $(\tilde{\delta})$ indicates that there are approximately $40 \%$ variations between desired and actual level of employment during the time period. The value of $\tilde{\zeta}$ as short-run returns to employment (1.055) seems high. It suggests that 
increasing returns to employment in manufacturing industries of Bangladesh.

Similarly since the computed value of h-statistic (1.0085) is in acceptance region in case of 95\% level of confidence, so we can accept the null hypothesis that residuals are serially independent.

Employment growth in Bangladesh manufacturing industries: $\mathrm{As}^{[31]}$ detected the structural stability of the break point as 1991-92 using Chow test. In addition, the reason of taking the break point as 1991-92 is that since the trade liberalization was introduced in the mideighties, its impact was found from the early nineties ${ }^{[32]}$. Annual growth rates in value added and employment have been studied in Bangladesh manufacturing industries for pre-liberalization period (1981-82-199091), post-liberalization period (1991-92-1999-00) and overall period (1981-82-1999-00) are shown in Table 2.

It has been observed that the growth rate of value added is higher in post liberalization period than preliberalization period. On the other hand the growth rate of employment is lower in post liberalization period than pre-liberalization period. It is clear that a decline has been occurred in case of employment in the postliberalization period. It implies that the performance of employment growth is not satisfactory in postliberalization period than pre-liberalization period, which is unexpected. It is seen that the overall growth rate of value added has declined to $0.9217 \%$ per annum whereas it was found 1.1193 at the post liberalization period. But the overall growth of employment has increased to $0.7660 \%$ per annum whereas it was found $0.6626 \%$ per annum at the post liberalization period. Finally we can say that the growth rate of value added exceeded the growth rate of employment in manufacturing industries in Bangladesh.

\section{CONCLUSION}

The results of the investigations which have been reported in this study have led us to the following conclusions: The model type I in comparison to the model type II of the relationship between value added and employment, which had been found to fit quiet well in Bangladesh manufacturing industries. In general, the coefficients have the anticipated values and signs and they are quiet significant. This study provides some significant results for value added and lagged employment. The value added elasticity of employment is very low for both employment functions even the value-added is positively related to employment for Bangladesh manufacturing industries. The coefficients of the lagged employment are found significantly positive for both employment functions. The coefficient of adjustment of employment to its desired level is about medium. The model type I shows that the speed of adjustment is not so bad in Bangladesh. The annual rate of technical progress is low for the manufacturing industries and technology is positively related to employment in Bangladesh.

The employment elasticity with respect to real wage rate is found negative and low (-0.251) that supports also the results of Felipe and McCombie ${ }^{[16]}$. Finally the short run returns to employment shows that increasing returns to employment in Bangladesh.

In comparing pre liberalization period, the growth of value added and employment per annum has increased and decreased respectively than that of post liberalization period. The overall trends in value added and employment have increased but the growth rates are not proportionately increased.

\section{ACKNOWLEWDGEMENT}

The researchers wish to acknowledge the support provided by Fundamental Research Grant Scheme, No. 203/PJJAUH/671128, University Sains Malaysia, Penang, Malaysia for conducting this research.

\section{REFERENCES}

1. Ahluwalia, I.J., 1985. Industrial Growth in India: Stagnation since the Mid-Sixties. Oxford University Press, Delhi, ISBN: 13: 9780195617870, pp: 235.

2. Anyadike-Danes, M. and W. Godley, 1989. Real wages and employment: A skeptical view of some recent empirical work. Manchester School Econ. Soc. Stud., 57: 172-187. http://ideas.repec.org/a/bla/manch2/v57y1989i2p17 2-87.html

3. Balali, H., S. Khalilian and K. Naderi-Mahdei, 2008. Estimation of employment and labor demand function in agronomy and horticulture sector of Iran. Am. Euras. J. Agric. Environ. Sci., 2: 91-96. http://www.idosi.org/aejaes/jaes2(supple\%201)/17. pdf

4. Ball, R.J. and E.B.A. St Cyr, 1966. Short-term employment functions in British manufacturing industry. Rev. Econ. Stud., 33: 179-207. http://www.jstor.org/stable/2974413

5. Brechling, F.P.R., 1965. The relationship between output and employment in British manufacturing industries. Rev. Econ. Stud., 32: 187-216. http://www.jstor.org/pss/2295824 
6. Brechling, F. and P. O'Brein, 1967. Short-run employment functions in manufacturing industries: An international comparison. Rev. Econ. Stat., 19: 277-287. http://www.jstor.org/pss/1926639

7. Briscoe, G. and D.A. Peel, 1975. The specification of the short-run employment function. Oxford Bull. Econ. Stat., 37: 115-142. http://ideas.repec.org/a/bla/obuest/v37y1975i2p115 $-42 . h t m l$

8. Bruno, G.S.F. A.M. Falzoni and R. Helg, 2004. Measuring the effect of globalization on labor demand elasticity: An empirical application to OECD countries, Flowenla Discussion Paper No. 2, Hamburg Institute of International Economics, Hamburg. http://www.migrationresearch.org/EastWest/dokumente/Flowenla02.pdf

9. Diwan, R.K. and D.N. Gujarati, 1968. Employment and productivity in Indian industries: Some questions of theory and policy. Artha Vijnana, 10: 29-67.

http://www.sciencedirect.com/science?_ob=Article URL

10. Dunlop, J.T., 1938. The movement of real and money wage rates. Econ. J., 48: 413-438. http://www.jstor.org/stable/2225435

11. Fajnzylber, P. and W.F. Maloney, 2005. Labor demand and trade reform in Latin America. J. Int. Econ., $\quad 66$ : $423-46 . \quad$ DOI: 10.1016/J.JINTECO.2004.08.002

12. Felipe, J. and J.S.L. McCombie, 2001. The CES production function, the accounting identity and Occam's razor. Applied Econ., 33: 1221-1232. http://www.informaworld.com/smpp/ftinterface?co ntent $=\mathrm{a} 713758650 \& \mathrm{rt}=0 \&$ format $=\mathrm{pdf}$

13. Felipe, J. and J.S.L. McCombie, 2003. Some methodological problems with the neoclassical analysis of the East Asian economic miracle. Cambridge J. Econ., 27: 695-721. http://cje.oxfordjournals.org/cgi/content/abstract/27 15/695

14. Felipe, J. and J.S.L. McCombie, 2005. How sound are the foundations of the aggregate production function? Eastern Econ. J., 31: 467-488. http://eprints.otago.ac.nz/269/

15. Felipe, J. and J.S.L. McCombie, 2008. What Can the Labor Demand Function Tell Us About Wages and Employment? The Case of the Philippines. In: Defense of Labor Market Institutions: Cultivating Justice in the Developing World, Berg, J. and D. Kucera (Eds.). ILO and Palgrave Macmillan, Basingstoke, ISBN: 0230538053, pp: 119-149.
16. Felipe, J. and J.S.L. McCombie, 2009. Are estimates of labor demand functions mere statistical artefacts? Int. Rev. Applied Econ., 23: 147-168. DOI: 10.1080/02692170802700492

17. Al-Towaijri, H.A., 1995. The specification of the functional form of the labor demand equation. J. King Saud Univ., 7: 119-127. http://digital.library.ksu.edu.sa/V7M193R1763.pdf

18. Haouas, I. and M. Yagoubi, 2004. Trade liberalization and labor-demand elasticities: Empirical evidence from Tunisia. IZA Discussion Paper No. 1084, Institute for the Study of Labor, Bonn, Germany. http://ideas.repec.org/p/iza/izadps/dp1084.html

19. Hasan, R., D. Mitra and K.V. Ramaswamy, 2007. Trade reforms, labor regulations and labor-demand elasticities: Empirical evidence from India. Rev. Econ. Stat., 89: 466-481. DOI: 10.1162/rest.89.3.466

20. Keynes, J.M., 1939. Relative movements of real wages and output. Econ. J., 49: 34-51. http://www.jstor.org/pss/2225182

21. Krishna, K.L., 1974. A Model for the Manufacturing Sector: Some Preliminary Results. In: Towards an Econometric Model of the Indian Economy, Chowdhury, N.K. et al. (Eds.). Part III, Indian Council of Social Science Research.

22. Krishnamurthy, K., 1985. Inflation and Growth: A Model for India in Krishnamurthy, K. and V.N. Pandit (Eds.). Macro Econometric Modeling of the Indian Economy, Studies in Inflation and growth. Hindustan Publishing Corporation, Delhi.

23. Maddison, A., 1964. Economic growth in the West. Twentieth Century Fund, 54: 1118-1121.

24. Michl, T.R., 1987. Is there evidence for a marginalist demand for labor? Cambridge J. Econ., 11: 361-373.

http://ideas.repec.org/a/oup/cambje/v11y1987i4p36 1-73.html

25. Morawetz, D., 1974. Employment implications of industrialization in developing countries. Econ. J., 84: 491-542. http://www.jstor.org/pss/2231038

26. Morgan, P., 1980. Short-term employment functions and the quasi-fixity of labor: A note. Applied Econ., 12: 491-496. http://ideas.repec.org/a/taf/applec/v12y1980i4p491 $-96 . h t m l$

27. Shaikh, A., 1974. Laws of production and laws of algebra: The humbug production function. Rev. Econ. Stat., 56: 115-120. http://ideas.repec.org/a/tpr/restat/v56y1974i1p11520.html 
28. Shaikh, A., 1980. Laws of Production and Laws of Algebra: Humbug II. In: Growth, Profits and Property: Essays in the Revival of Political Economy, Nell, E.J. (Ed.). Cambridge University Press, Cambridge, ISBN: 10: 0521223962, pp: 115-164.

29. Slaughter, M.J., 2001. International trade and labor-demand elasticities. J. Int. Econ., 54: 27-56. DOI: 10.1016/S0022-1996(00)00057-X

30. Smyth, D.J. and N.J. Ireland, 1967. Short-term employment functions in Australian manufacturing. Rev. Econ. Stat., 35: 537-544. http://www.jstor.org/pss/1928339

31. Sumonkanti, D., B.M. Azizul, R.M. Masud and K.M. Abdul, 2008. Analysis of the growth of manufacturing industries in Bangladesh. South Asia Econ. J., 9: 85-108. http://elin.lub.lu.se.elin.asiaportal.info/elin?func=re cord \&start $=14 \&$ query $=$ bangladesh $\&$ sessionId $=9 F 0$ CBBBE5C079842578D880E1746DAC0\&orgFunc $=$ simpleSearch $\&$ ftxtOnly $=\&$ sdi $=$
32. Williamson, J.G., 1971. Capital accumulation, labor saving and labor absorption once more. Q. J.

Econ., 85: 40-65. http://www.jstor.org/pss/1881839

33. Wilson, T.A. and O. Eckstein, 1964. Short-run productivity behavior in US manufacturing. Rev. Econ. Stat., 21: 41-54. http://www.jstor.org/pss/1924075 